$6-2013$

\title{
1976 Montreal Olympics: Case Study of Project Management
}

\section{Failure}

Ashish Patel

HWH Architects Engineers Planners, Inc, abp@hwhaep.com

Paul A. Bosela

Cleveland State University, p.bosela@csuohio.edu

Norbert Delatte

Cleveland State University, n.delatte@csuohio.edu

Follow this and additional works at: https://engagedscholarship.csuohio.edu/encee_facpub

Part of the Civil Engineering Commons, and the Construction Engineering and Management

Commons

How does access to this work benefit you? Let us know!

\section{Publisher's Statement}

(C) ASCE

\section{Original Citation}

Patel, A., Bosela, P., and Delatte, N. (2013). "1976 Montreal Olympics: Case Study of Project Management Failure." J.Perform.Constr.Facil., 27(3), 362-369.

This Article is brought to you for free and open access by the Civil and Environmental Engineering at EngagedScholarship@CSU. It has been accepted for inclusion in Civil and Environmental Engineering Faculty Publications by an authorized administrator of EngagedScholarship@CSU. For more information, please contact library.es@csuohio.edu. 


\title{
1976 Montreal Olympics: Case Study of Project Management Failure
}

\author{
Ashish Patel ${ }^{1}$; Paul A. Bosela, F.ASCE ${ }^{2}$; and Norbert J. Delatte, F.ASCE ${ }^{3}$
}

\section{Introduction}

On May 12, 1970, extensive lobbying and diplomacy by Montreal Mayor Jean Drapeau paid off when Montreal was awarded the 1976 Olympic Games over strong bids from Moscow and Los Angeles. Although both competing cities provided financial guarantees, Drapeau stated that the Games would cost a maximum of $\$ 124$ million and that the history and reputation of Montreal would stand in place of a guarantee (Auf der Maur 1976).

For the next few years, very little was done. The original plan was scrapped. Mayor Drapeau became enamored with architect Roger Taillibert's Parc des Princes in Paris. Tellingly, the construction cost for that stadium had ballooned from the original estimated $\$ 9$ million to a final cost of $\$ 25$ million. Drapeau selected Taillibert without a competition. Like Taillibert, Drapeau had had previous problems with cost overruns. The Olympic bid was based in part on Montreal's successful hosting of the 1967 Expo. However, the final cost of the Expo was $\$ 430$ million-much more than the 1964 estimate of $\$ 160$ million. A new plan was laid out in a press conference on April 6, 1972. Almost 2 years of preparation time had been wasted (Auf der Maur 1976).

In November 1972, Drapeau gave a figure of $\$ 310$ million as the total projected cost of the Olympic Games. Of the $\$ 250$ million in capital expenditures in the budget, $\$ 130.8$ million was for the stadium and \$16.4 million for the velodrome. The Olympic Village was listed under noncapital expenditures as $\$ 5$ million. Howell terms this Drapeau's kitchen-table budget that no one ever took seriously but that also no one ever gathered the data to challenge. It was suspicious from the start, however, because the recently concluded Munich Games had cost the equivalent of $\$ 600$ million. Shortly afterward, in January 1973, Drapeau made his often-quoted (and often-derided) statement that "the Montreal Olympics can no more have a deficit than a man can have a baby" (Howell 2009). Howell later observed that "amazingly, every time the Mayor revised his cost estimate, we believed that it was correct at last" (Howell 2009).

Drapeau laid out a plan for $\$ 310$ million in financing, the bulk of which would come from the sale of $\$ 250$ million in Olympic commemorative coins. The federal government of Canada reviewed the budget and thought that $\$ 100$ million in coin sales would be more realistic. The federal government did not want to get stuck with the bill for the construction or the Games. The city of Montreal had made the commitment, and Canada and the Province of Quebec did not wish to be responsible for fulfilling that commitment. Strangely, they seemed to think that the construction cost estimates were in the ballpark. At this point in the process, Drapeau suggested at a news conference that the real problem would be figuring out how to spend the surplus from the first self-financing Games in Olympic history (Howell 2009).

The extensive construction of the Olympic facilities was justified, in part, on the idea that the facilities could be used after the Games for other sports, specifically using the Olympic Stadium for the Montreal Expos baseball team. However, the potential users were not consulted during the planning process (Howell 2009). The suitability of the facilities for use after the Games ended will be discussed later in this paper

James Neal begins his textbook, entitled Construction Cost Estimating Concepts and Their Applications (Neil 1979), with an eight-page case study of the Montreal Olympics complex. Nick Auf der Maur, a newspaper columnist and member of the Montreal City Council, wrote The Billion-Dollar Game: Jean Drapeau and the 1976 Olympics about all the problems (Auf der Maur 1976). 
In late July 1976, at the final session of the World Congress on Space Structures, a highly controversial panel discussion was held on the project, which was later documented in ASCE's Civil Engineering magazine. It included some prominent consulting engineers from the United States, such as Anton Tedesko and Lev Zetlin, and some engineers and architects from Canada and elsewhere. A sidebar to the article summarized some of the comments that had appeared in the Montreal Star newspaper under the title, "Cost-BeDamned Attitude Brought on Olympic Woes" (Civil Engineering 1976).

This paper has been assembled from a variety of sources rather than firsthand observations. As such, it could be subject to the biases of the authors of the source information and may be inadvertently slanted. Care has been taken to balance the opposing viewpoints as much as possible.

\section{Olympic Games, Politics, and Prestige}

The quadrennial Olympic Games are so prestigious that cities and countries commit substantial resources to bidding for the right to hold them and then invest heavily in the facilities in which to hold them. For the 1976 Games, Moscow and Los Angeles both bid against Montreal, and concerns about cold war politics weighted the scales in Montreal's favor. Moscow would host the 1980 Games, boycotted by the United States and its allies, and Los Angeles would host the 1984 Games, boycotted by the Soviet Union and its allies, showing that the concerns about politics were well-founded. The Montreal Games also took place against the backdrop of the 1972 Munich Games and the hostage crisis that resulted in the death of Israeli athletes. After 1972, there were concerns about how the Games could go on, if they should, and how they could be kept safe.

Kidd (1992) contends that the politics of Canada, Quebec, and Montreal played a large part in the difficulties of the 1976 Games. Much of the tension was brought about by the resurgence of Quebec's Francophone nationalism and the succession movement. In addition, Montreal had long been dominated economically, politically, and culturally by a small Anglophone elite that was at odds with the Quebec nationalism movement. The federal government of Canada supported Montreal's bid reluctantly and ruled out direct financial support for the Games. Furthermore, Mayor Drapeau and Canadian Prime Minister Pierre Trudeau did not trust each other. As a result, it took a long time to set up the Olympic lottery and coin and stamp program to support the Games, which cost 34 months of lead time. The program was slowed by unpaid bills until the Province of Quebec reluctantly agreed to accept responsibility for any deficit in early 1973.

The potential embarrassment of missing the opening of the Games provided a fixed construction deadline. The planning started about 2 years too late, and scheduling fell apart because it was physically impossible to accommodate all the construction activities on the project site. The City of Montreal was too slow in preparing bid documents, so the work could not be competitively bid but was instead awarded to selected contractors. Double crews, double shifts, and overtime were used to attempt to increase productivity, but because of congestion, the increase in productivity was slight (Neil 1979).

Political turmoil intervened during the Montreal Games. Canada refused to allow the Republic of China (Taiwan) to compete because Canada had recognized the People's Republic of China in 1970, despite the fact that the Republic of China was a member of the International Olympic Committee (IOC). This caused considerable friction with the United States. A much larger issue came about involving New Zealand's participation in the Games because the
New Zealand rugby team had just played in South Africa, and South Africa was barred from the Olympics during the apartheid era. Just before the Montreal Olympics started, 28 African countries walked out of the Games, joined by Guyana and Iraq (Strenk 1978).

The issues of the politics and prestige of the Olympic Games have continued since Montreal. "There's a myth growing, on this Olympic mess, that it all started with the tacky, overcommercialized Summer Games in Atlanta. Which led to all the bribes and greed of Salt Lake City. It's a nice myth, but it's wrong. The real sleaze got its start with Jean Drapeau and the 1976 Olympic Games in Montreal. There was the blueprint for corruption." (Fotheringham 1999, p. 76).

\section{Montreal Olympic Complex}

The Montreal Olympic complex consisted of a main stadium, a velodrome (bicycle racing venue), roads, walkways, practice fields, an Olympic Village housing facility, and other structures and landscaping. The complex is shown in Fig. 1.

Planning began in 1970, and preliminary estimates prepared at that time indicated a projected cost for the entire complex of $\$ 120$ million, including a projected cost for the main stadium of $\$ 40$ million. The final cost in 1976 was $\$ 1.5$ billion, with $\$ 836$ million for the main stadium. In addition to the cost overruns, there were considerable time overruns, which meant that the complex was almost not completed in time for the Olympics, and some of the final activities were still ongoing at the time the Olympics started. Major components originally planned, such as the retractable roof, were not begun until after the Olympics (Neil 1979).

The original owner was the City of Montreal, Quebec, which contracted with architect Roger Taillibert to design the Olympic Park, including the Olympic Stadium and velodrome (Auf der Maur 1976). Mr. Taillibert lived and conducted business in Paris, France. Both the velodrome and Olympic Stadium were relatively unusual, unique artistic creations.

The Mayor of Montreal, Jean Drapeau, has been criticized for an almost worshipful attitude toward Taillibert. The mayor rejected cuts that could have saved up to $\$ 146$ million. He insisted on building the stadium of concrete rather than steel because Taillibert was a precast-concrete expert-although a steel stadium might have cost $\$ 100$ million less (Civil Engineering 1976).

Taillabert, who was to be paid \$10-15 million for his work, did not help public relations with his lack of modesty, saying “That's all

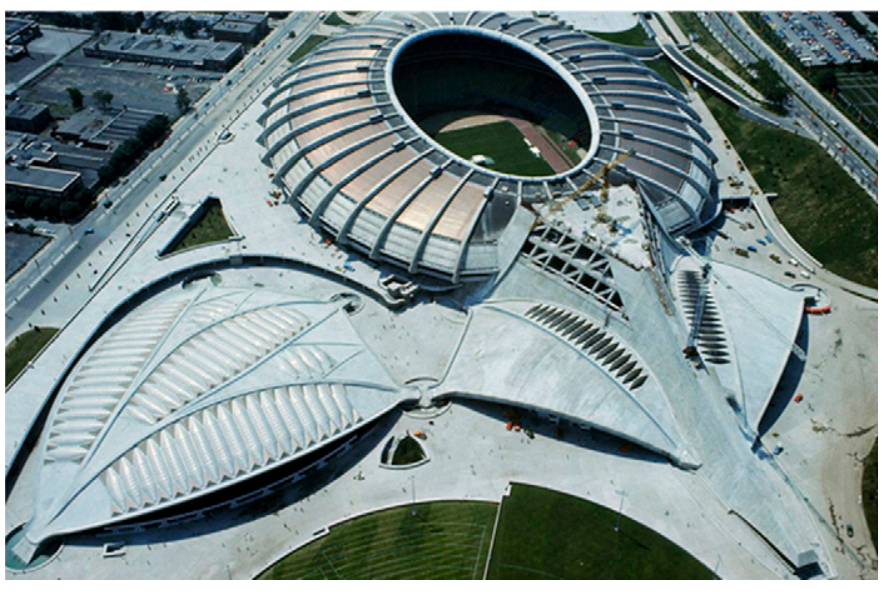

Fig. 1. Olympic Stadium complex during the 1976 Olympic Games (Parc Olympic Quebec 2011; credit: Olympic Park of Montréal) 
Canadians and North Americans talk about-money, money, money. It doesn't interest me at all," telling a reporter "Are you aware that the building of the stadium and velodrome constitutes a great moment in the history of architecture and technology?" (Civil Engineering 1976).

\section{Velodrome}

Prior to bidding for the Olympic Games, the City of Montreal had already committed to hosting the World Cycling Championships in the Olympic velodrome for the summer of 1974. Construction of the velodrome began in August 1973, a year in advance of the scheduled opening of the Championships on August 14, 1974. However, it turned out that the rocky subsoil was not solid enough to support the roof - a fact that had not been found by geologic soundings and subsurface tests. The location near the Saint Lawrence River, however, hinted at probable subsurface difficulties. The foundation problems, along with labor union conflicts, ensured that the velodrome could not open in time for the Championships. A temporary facility was quickly built at the University of Montréal football stadium. The makeshift site had an excellent view of Mount Royal and would have served very well for the Olympic Games, although the spectator capacity would have been less. The incident highlighted the problems with the Olympic construction, but by this time there were less than 2 years left to go (Howell 2009).

The contract for the velodrome construction was awarded to prime contractor Charles Duranceau with a $\$ 12$ million bid, based on half-complete plans, in August 1973, and construction began later that year. It was the first and last contract of the Montreal Olympics issued through public bidding (Auf der Maur 1976).

The velodrome consisted of three arches supported by abutments. It was designed to have the appearance of a cycling helmet, as shown in Fig. 2. The structure consisted almost entirely of arches

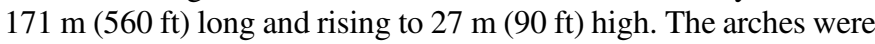
made of precast-concrete sections positioned onto falsework on site and then posttensioned (D'Appolonia 1990).

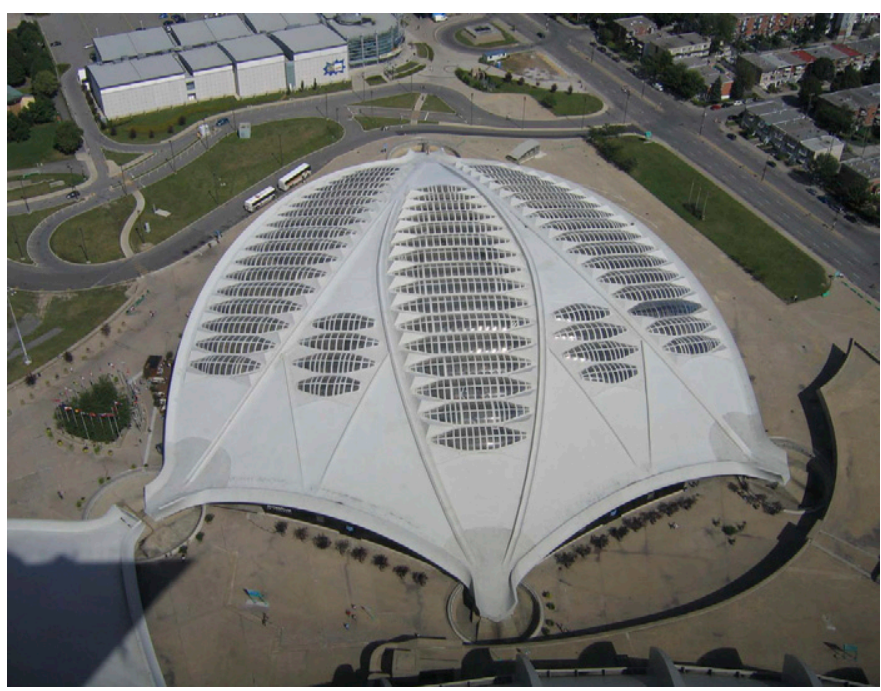

Fig. 2. Velodrome, now a biodome (Wikipedia Commons, http:// en.wikipedia.org/wiki/File:Biodome_Montreal.jpg, photograph by PtitLutin)
The horizontal component $H$ of the arch thrust is given by

$$
H=\frac{q L^{2}}{8 d}
$$

where $q=$ uniform load along the arch, $L=$ span of the arch, and $d=$ height of the arch. For a given span $L$, as the depth decreases, the horizontal force increases. The low aspect ratio $d / L$ of the arch, about $1: 6$, produced very high horizontal thrust forces.

The arch was supported by four abutments, designated $\mathrm{W}, \mathrm{X}, \mathrm{Y}$, and $\mathrm{Z}$ in Fig. 3. Abutments $\mathrm{X}$ and $\mathrm{Y}$ were founded on good rock, but the rock was of questionable quality at Abutments $\mathrm{W}$ and $\mathrm{Z}$. Additional investigations showed that the rock was broken up to a depth

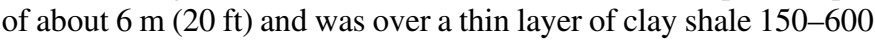
$\mathrm{mm}$ ( 6 in. to $2 \mathrm{ft}$ ) thick. The thin layer represented a potential slip surface for the abutments, and as a result, tendons had to be driven through that layer into competent rock (D'Appolonia 1990) (Fig. 4). Abutment Z, unlike the other three abutments, takes the combined thrust of three arches and, as a result, has to resist the highest forces.

A critical construction operation was the decentering, or removal of the supporting falsework for the arches. The process would create the greatest loads on the abutments, about 32,000 tons on Abutment Z. A total of 36 jacks were used, each with a stroke of $25 \mathrm{~mm}$ (1 in.). Only $13 \mathrm{~mm}$ (0.5 in.) of displacement could be tolerated during decentering, and the operation was carefully monitored (D'Appolonia 1990).

The soil problem of low bearing capacity and the high loads on the abutments had resulted in substantial time delays and cost overruns for the foundation work. Although the foundation of the velodrome had been estimated to cost $\$ 497,576$, the final cost was $\$ 7,171,876$ because of the extensive grouting and anchorage system shown in Fig. 4. A large part of the construction delay was because the contractor had to wait on Taillibert to finish the plans. Once the final plans were received, it was necessary to develop construction plans for the falsework. The work quickly fell behind, and it was

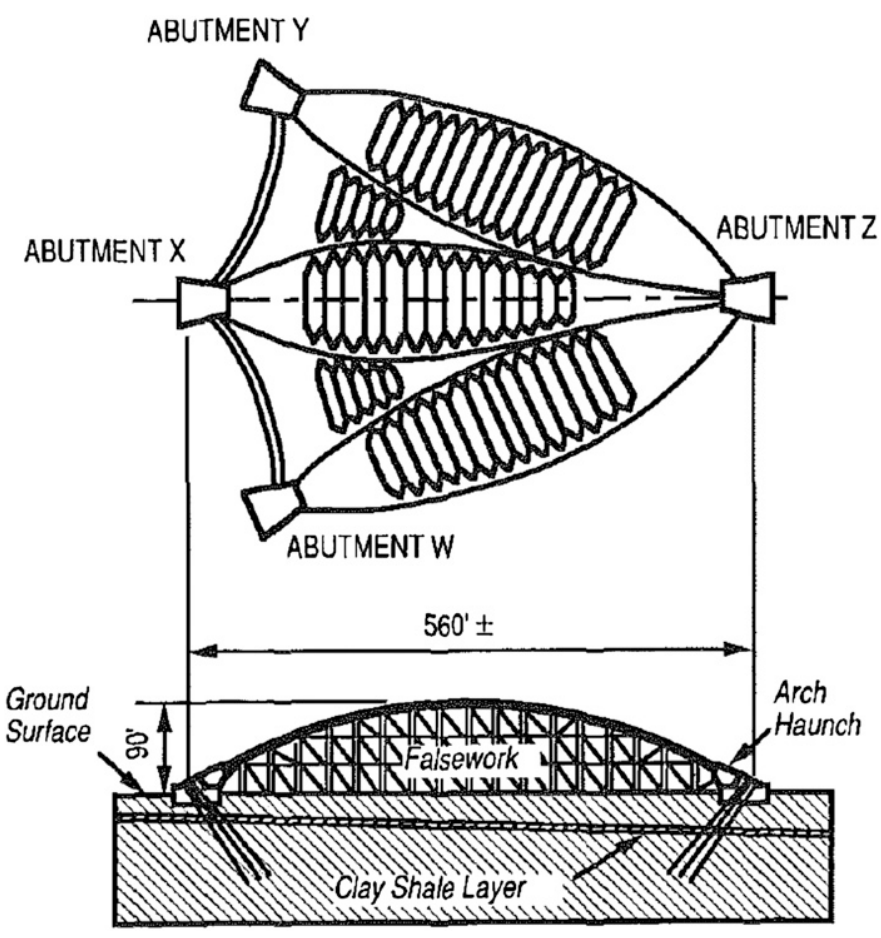

Fig. 3. Plan and elevation of velodrome $(1 \mathrm{ft}=0.3 \mathrm{~m})$ 
obvious that the 1974 date could not be met. More workers were hired, and extensive overtime was authorized, but the extra workers mostly got in each others' way. By late fall 1974, \$34 million had been spent on the velodrome, and it was not complete. New subcontractors were hired. Given the time constraints, most of the construction contracts were cost plus rather than low-bid fixed-cost contracts. There also were a number of labor problems, such as tasks taking too long, strikes, overtime, and extra equipment, which themselves added about $\$ 12$ million to the project cost (Auf der Maur 1976).

The final cost for the 7,000-seat velodrome was approximately $\$ 70$ million, compared with a $\$ 60$ million cost for a 60,000 -seat domed stadium in Seattle, Washington, at the same time. The cost per seat was 10 times as high. There also remained the concern that acrylic panels in the roof posed a fire hazard (Auf der Maur 1976).

Anton Tedesko was known for his efficient thin-concrete-shell structures, epitomized by the Hershey Arena that spanned $67 \mathrm{~m}$ $(220 \mathrm{ft})$ with a shell only $89 \mathrm{~mm}$ (3.5 in.) thick (Billington and Billington 2006). He was strongly critical of the velodrome, stating that it should have had a greater construction depth (or height) that would have greatly reduced the forces. As Eq. (1) shows, $H$ is inversely proportional to $d$. It could also have been more structurally efficient if the dome and three-dimensional action had been considered in the design. Tedesko stated that the structures "do damage to the cause of concrete. Our young people should be told that these structures did not have to be done this way. As built, this gigantic demonstration project is almost an argument against the use of concrete and for the use of structural steel or aluminum under similar circumstances in the future" (Civil Engineering 1976, pp. 50-51).

The velodrome was renovated starting in 1989 and transformed into a biodome managed by the City of Montreal in 1992. It is now part of the Montreal Nature Museum (Parc Olympique Quebec 2011).

\section{Olympic Stadium}

All the structures were dramatic, modern, and complex, none more so than the main stadium. The stadium may be seen in the upper

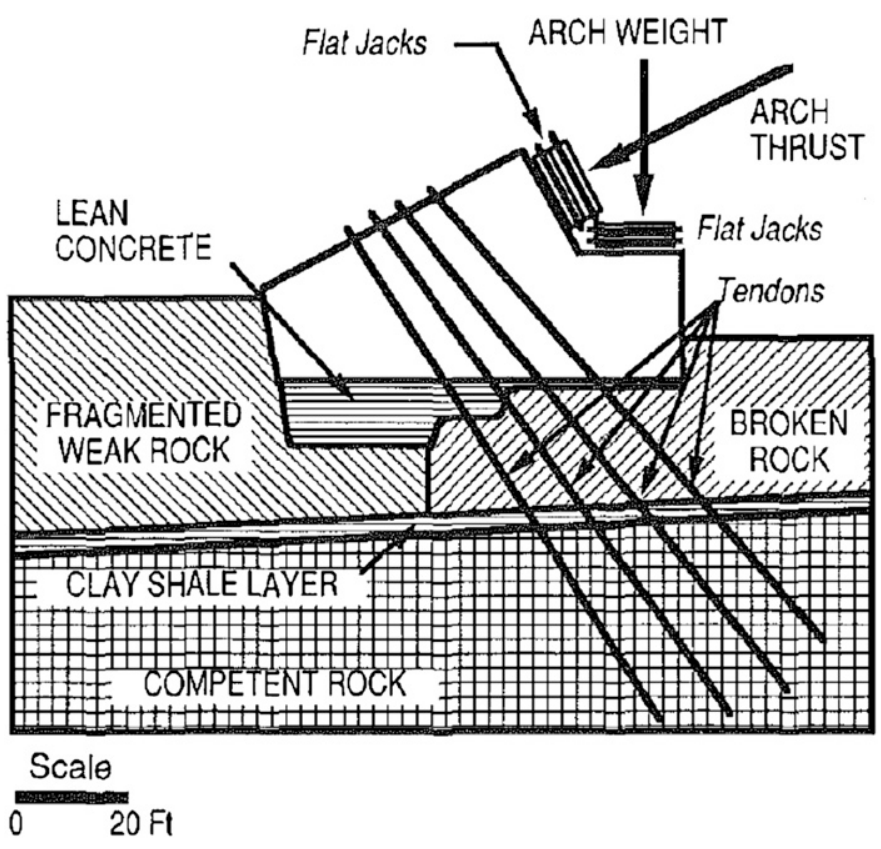

Fig. 4. Typical arch abutment (Abutment $\mathrm{Z}) \quad(1 \mathrm{ft}=0.3 \mathrm{~m})$ right of Fig. 1 and in its final configuration in Fig. 5. The stadium had a number of unusual features. It was intended to resemble an elliptical seashell with a handle, which would have a retractable fabric cover hanging from a tall mast over the opening. As Fig. 1 shows, the mast and cover were not in place at the time of the Olympics (Neil 1979). They were added later and may be seen in Fig. 5.

The general structural form appears to be a large elliptical dome with an opening in the middle for the fabric roof. If it were, in fact, a thin dome with a compression ring, it would be an efficient structural form. However, it isn't. The main structural members are complex precast concrete ribs, shown in Fig. 6. The ribs cantilever out over the stadium, and although the hollow ring inside the roof carries lighting and other support systems, it is not designed to carry compression forces. Because of the gentle slope of the roof, each pair of ribs is a different size. The ribs were glued and posttensioned. They proved to be very difficult to erect, so misalignments of the ribs were as much as $150 \mathrm{~mm}$ (6 in.). This was a problem because the posttensioning cables had to be threaded through tubes in the ring. During the winter, some empty posttensioning ducts became full of ice, and considerable time and expense were involved in removing

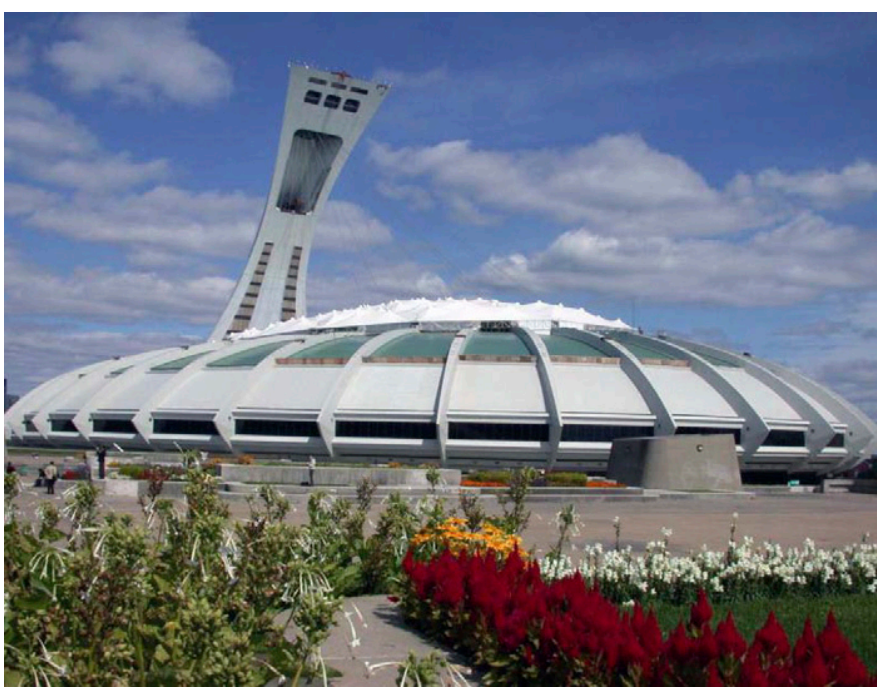

Fig. 5. Olympic Stadium (Wikipedia Commons, http://en.wikipedia. org/wiki/File:Le_Stade_Olympique_3.jpg)

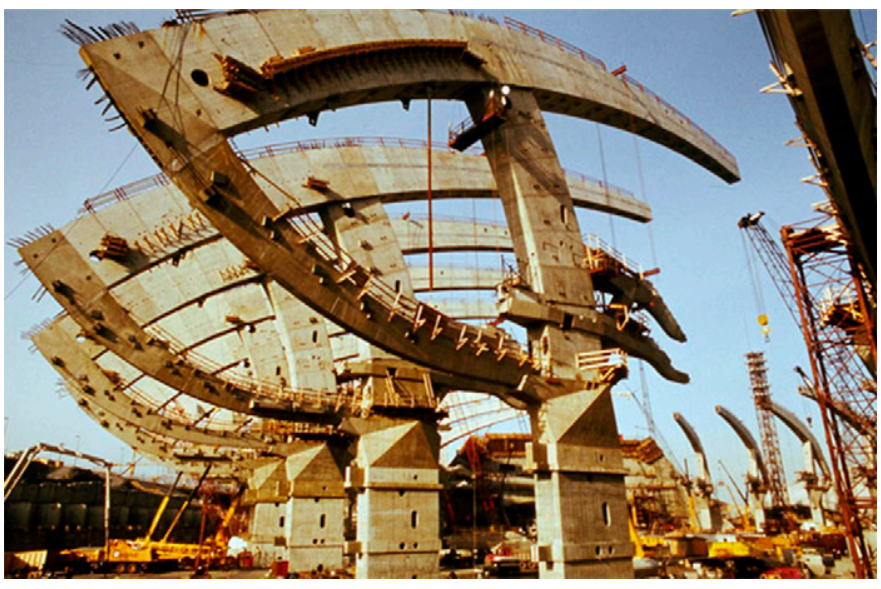

Fig. 6. Ribs of the Olympic Stadium (Parc Olympic Quebec 2011; credit: Olympic Park of Montréal) 
the ice (Neil 1979). It has been estimated that if all the ribs had been the same size, \$20-30 million could have been saved (Civil Engineering 1976).

Furthermore, the stadium design did not consider constructability and did not leave room for interior scaffolding. Many cranes were used instead, some holding ribs, and others holding workers, tools, and materials. Fig. 7 shows the congestion of cranes in the stadium. At one point, 80 cranes were used in the main stadium, and it was estimated that doubling the number of cranes only increased productivity $25 \%$ because they could not work effectively given that they were in each other's way (Neil 1979).

"At one stage, there was a forest of 200 building cranes on the stadium site, some from as far as Calgary, while gravel truck drivers gleefully drove in, collected their fee, and then drove out the other end, unloaded, and just went around the block again. Skilled workers, at seven 10-hour shifts a week, pulled down $\$ 1,500$ weekly by doing only 2 hours a day of actual work" (Fotheringham 1999, p. 76).

Although epoxy-glued, posttensioned construction had been used successfully in Europe, it was new to the North American contractors. As with any new technology, there was a difficult learning process (Neil 1979). With the time constraints on this project, the use of an unfamiliar technique was not a good idea.

Taillibert did not deliver the plans and specifications for the Olympic Stadium until the late summer of 1974 . He had already gained a reputation for late delivery of construction documents. The contract to build the Olympic Stadium was awarded to Desourdy and Duranceau, as cost plus $\$ 9$ million profit with a $\$ 1$ million bonus if the site were ready on time. The contract was awarded without public tenders. It was a strange choice of contractor, given that Duranceau was already buried in difficulties with the velodrome. The Province of Quebec forced the hiring of Lalonde, Valois, Lamarre, Valois \& Associates (known as Lalonde, Valois) as project manager over Drapeau's resistance. The cost estimates of Lalonde, Valois proved to be no better than any of the others (Auf der Maur 1976).

At the beginning of 1975, the Olympic Organizing Committee (referred to as COJO from Comité de contrôle des Jeux olympiques) was very concerned about completion of the stadium and began to look for alternatives, such as finding or building a cheaper stadium nearby. Mayor Drapeau called an elaborate press conference to explain the cost projections and provide assurances that the stadium would be ready on time. He referred to a funding gap of $\$ 200$ million,

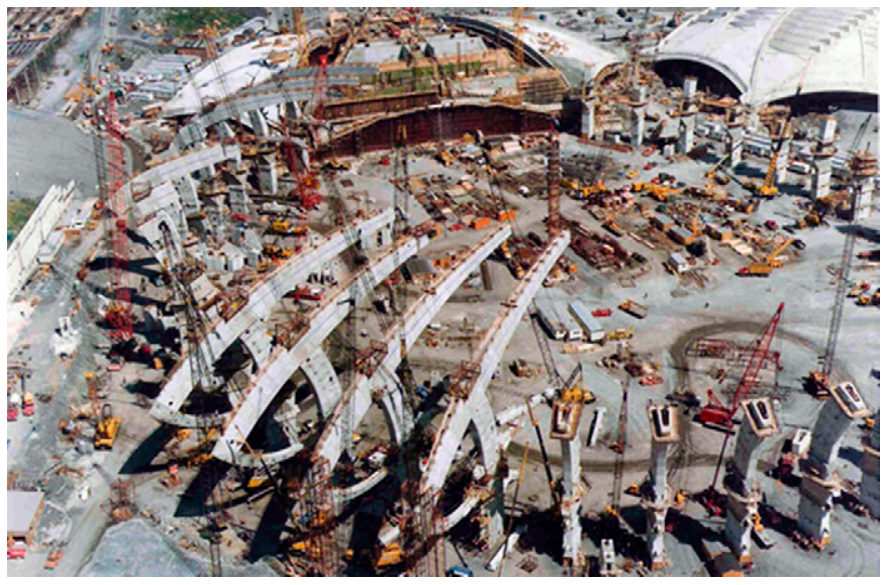

Fig. 7. Cranes at work in the Olympic Stadium (Parc Olympic Quebec 2011; credit: Olympic Park of Montréal) refusing to call it a deficit. The alternate-stadium concept was scrapped (Auf der Maur 1976).

Very generous terms were given to the precasters who built the concrete ribs, including a $\$ 230,000$ rental of one plant for Olympic construction and a $\$ 500,000$ extension built onto another plant with public funds, plus $\$ 685,000$ in cash bonuses and honoraria. Precasting costs rose from $\$ 16$ million to $\$ 42$ million (Auf der Maur 1976).

Late in the game, Taillibert insisted on adding a water cascade to the top of the parking garages connected to the stadium, adding at least $\$ 8$ million to the cost. The parking garages, originally budgeted for an extravagant $\$ 25$ million, cost $\$ 60$ million, or about $\$ 13,000$ per parking space. The water cascade also would require 113 million L (30 million gal) of water (Auf der Maur 1976).

Mayor Drapeau, with no engineering or architecture qualifications, had spent much time poring over plans and going to the construction site to give orders, which confused the workers. Then, on December 13, 1974, Drapeau sent a representative to a meeting to say that the stadium construction would cost substantially more. The project continued to be troubled by labor demonstrations and strikes. Finally, on November 19, 1975, the Province of Quebec created the Régie des Installations Olympiques (RIO) to complete construction of the Olympic Park and take over as owner. Drapeau and Taillibert were now off the site. In assuming control from the City of Montreal, however, Quebec also assumed the expense (Howell 2009).

Quebec advanced \$200 million for the project but in return had to delay other important construction in Montreal, such as the subway and a sewage treatment plant. At that time, Montreal was one of the few cities in the Western world still dumping raw, untreated sewage into a river. Bills were paid, and construction continued, with no better cost control than before (Auf der Maur 1976).

The final cost for the stadium was approximately $\$ 13,000$ per seat, compared with approximately $\$ 2,400$ per seat for the Superdome in New Orleans, Louisiana, constructed at approximately the same time (Neil 1979). The stadium was nicknamed the Big O because of its name and shape, but it later became known as the Big Owe ("Quebec's" 2006).

Tedesko and consulting engineer Lev Zetlin both criticized the stadium. Tedesko noted that anyone familiar with match-cast posttensioned precast-concrete construction would have predicted the difficulties encountered. Zetlin stated that a large-span structure should be light, permit a large margin of error in the field, and use construction methods that were as simple as possible, and the Montreal Olympic Stadium violated all these principles. He further criticized the heavy roof as a dead weight on top of the building (Civil Engineering 1976).

After the 1976 Olympics, the Olympic Stadium saga continued. It was found that the tower could not be completed as planned in concrete without major structural work because it would be too heavy and that the tower would be overstressed by the Canadian standard ("Court" 1983). The tower was completed in steel and was damaged by a fire during construction ("Fire" 1986). The roof and tower were completed, but the retractable Kevlar roof was not installed until 1986 and was stored in France and then Montreal at a cost of several million dollars. In 1989, the roof developed huge tears because of air pressure ("Experts" 1989). In 1991, a 55-t chunk of the roof fell after support beams snapped, forcing an extended closure. Fortunately, there were no injuries. All 33 beams had to be reinforced at a cost of several hundred thousand dollars. The failure may have been because of the use of an improper (e.g., not corrosionresistant) type of steel or poor welding ("55-ton" 1991; "Suspect" 1991). Finally, RIO decided to replace the roof ("Fixing" 1993). The new roof tore again in the winter of 1999, forcing the cancellation of an auto show and a subsequent boat show ("Stadium" 1999). 


\section{Olympic Village}

The Olympic Village project began in 1970, when at the presentations to win the Olympic bid in Amsterdam, Jean Drapeau announced that the Olympic Village would be a low-rise structure that would be placed just to the east of the Olympic Stadium and Velodrome. The mayor said that the village would be used to provide for 4,000 low-cost housing units after the Olympics were over, serving up to 14,000 tenants. The concept would fit in well for his self-financing Olympics because the Central Mortgage and Housing Commission (CMHC) would provide $95 \%$ of the clearance cost and $75 \%$ of the construction cost (Auf der Maur 1976).

There was a great debate on both where to place the Olympic Village and whether the village would be centralized or spread out. There were many protests against placing the complex in Viau Park because it would take away green space from a city that didn't have much of it. However, at the end of 1972, Mayor Drapeau announced that the Olympic Village was going to be built in the park and that the village would be centralized, over all objections. The city also destroyed 125 elm trees on the site after promising not to remove any (Auf der Maur 1976).

"In January 1974, a group from Montreal arrived in Baie des Anges, on the Côte d'Azur in southern France, the site of a spectacular pyramid-shaped condominium complex designed by architect André Minangoy. The visitors, who included Montreal developer Joseph Zappia, told the sales director of the Baie des Anges project that they had been selected to build the Olympic Village for 1976. This was odd because the deadline for tenders was not until March 1, almost two months in the future" (Auf der Maur 1976).

When the project went out to bid, 53 different groups or companies had paid the $\$ 100$ to pick up the preliminary specifications and requirements. However, as the March 1 deadline came and went, the city announced that there were no suitable proposals and that the deadline was going to be postponed indefinitely. As time went on, many of the bidding companies never heard anything at all from the city regarding their respective bids. For example, a British developer had spent in the vicinity of $\$ 400,000$ to develop a private plan, which required no excess public money. The bid was submitted in the summer of 1973, well before the deadline. Unfortunately for the developer, his company never received a yes or a no regarding the subject. After never receiving a reply, the developer packed up, left, and vowed that he would never conduct business in Quebec again. Other strong bids were also ignored (Auf der Maur 1976).

At a meeting on June 28, 1974, Mayor Drapeau announced that a group called Las Terrasses Zarolega would construct the Olympic Village. It seemed to be the first indication for most that Zarolega even existed. Although the original call for proposals specified 1,800 units (mysteriously down from 4,000), Zarolega proposed to build only 932 units. To house 12,000 athletes, as many as 12 people would have to sleep in the larger two-bedroom units, and many would have to sleep in the kitchens. The design was ill suited for Montreal's cold winters because there were no indoor corridors, and the units had to be accessed by walking up to $180 \mathrm{~m}(600 \mathrm{ft})$ along exterior balconies open to the wind. The previously mentioned Zappia was one of the four partners of Zarolega (Auf der Maur 1976).

Responsibility for construction of the Olympic Village had been left vague until very late in the process. The original idea was that either a private developer or the city's public housing commission would develop the village and keep it separate from COJO. On October 22, 1974, Lord Killanin, head of the IOC, phoned to say that if the City of Montreal did not have a contract in place by the time of the IOC's upcoming Vienna meeting (October 20, 1974), the IOC would consider transferring the Games to another city. The Olympic Village task became the responsibility of COJO, mostly because Drapeau was so far behind. The original budget had not included the village under the premise that it would be built, financed, and owned by the private sector with funding support from the city's public housing through the CMHC. It turned out, however, that the pyramid configuration disqualified the project for CMHC funding-only buildings that had widths greater than their heights could be supported. This could have, and should have, been determined much earlier in the process (Howell 2009). Another reason given by Zarolega for the lack of CMHC support was that units in the $\$ 20,000-\$ 60,000$ price range hardly qualified as low-cost public housing (Auf der Maur 1976).

Although the IOC tried to consider alternatives, it was clear that the Zarolega plan was locked in, and there weren't really any levers with which to negotiate. Cost estimates rose from the $\$ 30$ million estimated by Zarolega on October 19, 1974, to $\$ 70$ million. On March 7, 1975, the IOC contracted with Hanscomb Roy and Associates to oversee the Olympic Village construction. There were concerns that $\mathrm{COJO}$ had no charter to own property and would be paying Zarolega twice, once before the Games and again for postGame renovations to resell the units for apartments (Howell 2009).

Zarolega received a generous cost-plus contract without a not-toexceed clause. The plus was $12 \%$ on the first $\$ 30$ million and $6 \%$ on anything above. Zarolega estimated that the project would not exceed $\$ 45$ million. Concerns about the potential cost led to the government committee hiring of a consultant for a second opinion. He predicted a project cost of $\$ 55-58$ million, with a possible $\$ 10$ million overtime bill. Despite the second opinion, the committee went with the Zarolega estimate. A number of problems occurred during the construction, including outrageous subcontracts, dangerous construction techniques, poor coordination, and theft. Many construction operations were managed so as to generate the highest costs and thus the highest profits, with profits on the work required to fix previous botched work. A new consultant was brought in to manage the construction, with limited success. The actual cost for the Olympic Village was approximately $\$ 70$ million. The project eventually resulted in a police raid and investigation (Auf der Maur 1976).

On completion of the complex structure in August 1975, there was a ceremony in which a tree was hoisted to the top of the building. Not long after all the dignitaries left, a piece of the eighth-floor balcony went crashing down onto the balconies below. After investigation, it was concluded that the balcony had failed owing to a lack of proper anchoring (Auf der Maur 1976).

The completed Olympic Village is shown in Fig. 8. The Olympic Village was intended to be sold as apartment buildings after the Games (Howell 2009). RIO managed the property after the Games, and by 1980, all 981 apartments had been rented, and the village had 2,000 residents. The Olympic Village was sold to private interests in 1998 (Parc Olympique Quebec 2011). It is hard to imagine that the purchase price was anywhere close to the $\$ 70$ million it cost to build the village because that would be more than $\$ 70,000$ per unit.

\section{Viaduct}

The main-road viaduct also had a relatively high construction cost because of its design. Although the main road was straight, the viaduct had a complex design, with curved faces and outstretched legs. The curved surfaces resulted in the inability to use standard, reusable formwork. The formwork cost for some parts of the viaduct was as much as $\$ 4,300 / \mathrm{m}^{2}\left(\$ 400 / \mathrm{ft}^{2}\right)$, about 15 times the cost of 


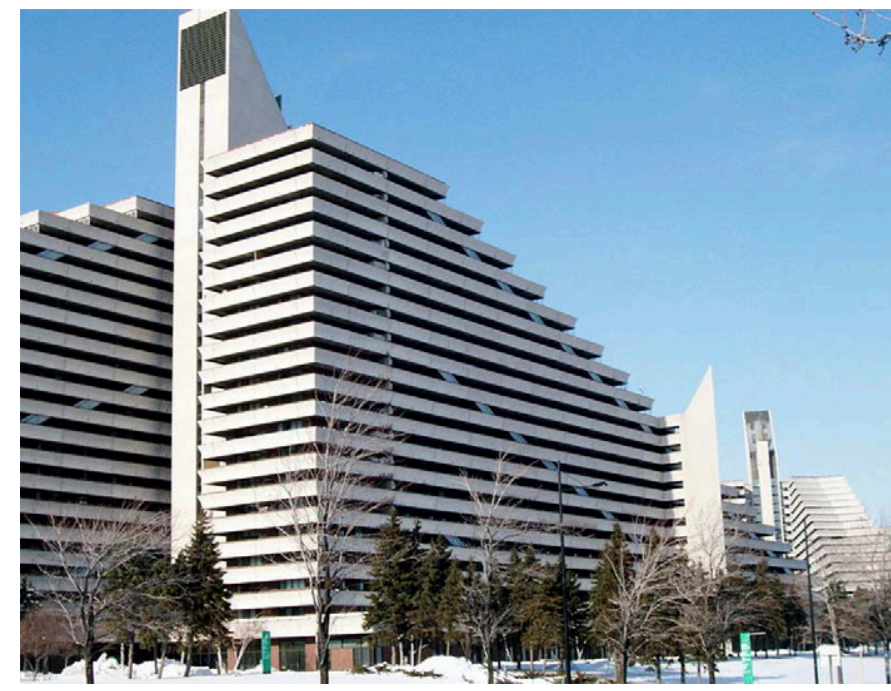

Fig. 8. Olympic Village (Wikipedia Commons, http://commons. wikimedia.org/wiki/File:Olympic_Village_Montreal_Jan_2008.JPG)

conventional formwork. Hence, the final cost of the viaduct was approximately $\$ 14$ million versus a projected cost of only $\$ 5$ million if a more conventional design would have been used. The project was so complex that no contractor would bid on a fixed-price contract. The contractor who built it demanded a cost-plus-fixed-fee contract under conditions that he would not be responsible for the final structure (Neil 1979).

The 180-m-long (600-ft-long) viaduct used a complicated inverted triangular pillar system for support. An engineering firm proposed changes, but Drapeau turned them down because they would interfere with Taillibert's vision. The contractor could not find scaffolding in Montreal, so new scaffolding was bought elsewhere for $\$ 1.5$ million (Auf der Maur 1976).

\section{Systemic Problems}

Neil (1979) discusses a number of systemic problems that affected all aspects of the Olympic Complex construction. He notes that union labor was used, and "approximately 80 days were lost to strikes and the equivalent of about another 20 days ... lost through slowdowns. The project had all of the qualities which tempt labor unions to take advantage of the client - there was a fixed schedule, labor was scarce, and there were no agreements between labor and management to restrict strikes" (Neil 1979).

With all the construction going on, labor and other resources became scarce. This added to project costs. Poor weather inhibited construction-not much a surprise given the northern climate of Montreal. At the peak, construction heating measures cost $\$ 400,000$ per day. In early 1976, the Province of Quebec issued an ultimatum that the workers had to speed up or the project would be shut down and the Games moved to other facilities. Following the ultimatum, in better weather, productivity increased $500 \%$. A plumbers' and electricians' slowdown delayed final turnover of the project by a week, until June 14, just 3 weeks before the start of the Games (Neil 1979). The extensive labor problems are described by Auf der Maur (1976). There were also 12 workers killed during construction (Auf der Maur 1976).

Another systemic problem was that all the design and engineering were done in France using the metric or Système International (SI) system of units. However, the project was built using the English system of units, and all the drawings had to be converted (Neil 1979).

\section{Discussion}

Others besides the mayor blindly defended Taillibert's work as art. Clement Vigneault, a structural engineer who collaborated with Taillibert, compared it to a Picasso painting. Tedesko retorted, saying that the Picasso painting should not be too large to fit in the building, criticizing the lack of functionality of Taillibert's designs. Others disagreed as to whether the engineers should just facilitate the architect's art, or use and social implications had to be considered as well. Overall, there was a consensus that Taillibert had developed his designs, and then the structural engineers were brought in late to try to make them work ("Experts" 1976).

Taillibert had received $\$ 6.8$ million but sued RIO for $\$ 32.6$ million in unpaid fees. RIO, in turn, countersued Taillibert for $\$ 18.6$ million, contending that his errors and omissions had caused inexcusable delays ("Court" 1983).

The Province of Quebec assembled a Commission of Inquiry on the Cost of the 21st Olympiad (Province of Quebec 1980). The charge of the committee was to study, in particular, the following:

1. The main causes of the increase in the cost of the Games and of the Olympic installations;

2. The division of responsibility for this increase;

3. The methods of organizing and supervising the work;

4. The possibility of collusion, influence peddling, and fraudulent or irregular activities;

5. The possibility of recovering some of the public funds used and the appropriate measures to be taken to this end; and

6. Effective prevention and control mechanisms to avoid the recurrence of such a situation in future major projects.

By and large the commission confirmed the allegations that Auf der Maur (1976) had made 4 years before, observing that Drapeau "appointed himself foreman and project manager" and "the choice of the Olympic Village design without a call for tenders or competition, solely because of Mayor Drapeau's fascination with the installations of the Baie des Anges Marina in France" (Province of Quebec 1980). The Commission blamed Mayor Drapeau, Taillibert, and COJO, noting also that the labor unions and the contractors and suppliers had rushed to take full advantage of the situation. Specific instances of corruption proved hard to document because few witnesses were willing to testify. To retire the debt, the City of Montreal borrowed $\$ 214$ million through a special Olympic tax on real property. Also, the Olympic lottery was extended until December 31, 1979, and a special tobacco tax had been imposed on May 12, 1976 (Province of Quebec 1980).

\section{Opposing View}

Paul Charles Howell wrote The Montreal Olympics: An Insider's View of Organizing a Self-Financing Games (Howell 2009) to address what he called errors of fact and interpretation that have routinely been reported in the media. He had been the head of planning for COJO.

Howell blames cost overruns on the oil crisis of 1973 and inflation, and says "Despite this, the Montreal Organizers raised the funds, paid for the staging of the Games, built and paid for the Olympic Village, provided and paid for many of the competition and training venues, and still handed over the considerable profit of nearly a quarter of a billion dollars to pay for its use of governmentowned facilities and cover city-incurred costs of construction" (Howell 2009). 
Howell also criticizes an often-used deficit figure of $\$ 2.192$ billion, saying that it "seems to include the cost of adding the tower and roof to the stadium after the games, converting the Velodrome to a nature museum, and the cost of the Olympic Village without the proceeds of the sale of the Olympic Village, plus all the late interest payments made" (Howell 2009)

Howell also makes the interesting comment that Drapeau committed to using the critical-path method (CPM) and the similar project evaluation and review technique (PERT), developed by the U.S. National Aeronautics and Space Administration (NASA), for the Games but not for the construction of the stadium, where it might have been very useful. Unfortunately, when the computer CPM/ PERT analysis was completed in November 1973, it projected that the work could not be completed before January 1977-6 months too late (Howell 2009).

\section{Conclusion}

On December 19, 2006, CBC News reported that the Olympic complex's debt had finally been paid off as of a month before. $C B C$ News noted, "After clinching the 1976 Olympics, the mayor of Montreal at the time, Jean Drapeau, boasted the Games would be the first auto-financed Olympics" (“Quebec's” 2006).

There are a number of technical, procedural, and ethical issues that contributed to the problems experienced by the Montreal Olympics project. There was an unrealistic deadline for the project. The City of Montreal was so late with design documents that most work packages could not be bid. Instead, most of the contracts were negotiated.

Project scheduling was forced to fit extremely tight deadlines. A proper construction schedule is based on normal crews and construction activity durations so that individual activities on a critical path can be intelligently expedited or crashed, to prudently compensate for project delays while minimizing increased costs. The unrealistic nature of the schedules made it impossible to intelligently crash selected activities.

Despite the lack of time available, unusual construction technologies were adopted. It was extremely difficult and labor-intensive to construct the stadium with the precast posttensioned epoxyconnected ribs of varying sizes. The use of one-of-a-kind, singleuse formwork for the curved surfaces of the viaduct also resulted in increased costs.

The time constraints and schedule compression resulted in even more simultaneous activities and an extremely crowded work space. At one point there were 80 different cranes trying to operate in the stadium. This resulted in cranes waiting for other cranes to finish their lifts, and crews standing around waiting for their turn. Doubling of the amount of cranes used on the job substantially increased the equipment cost but only increased the productivity by $25 \%$.

Given the size of the project, there was a shortage of local resources. Labor, material, and equipment had to be brought in from other areas. This resulted in additional transportation costs. It also resulted in poorer-quality labor, as well as nonlocal labor not having the same sense of civic pride as regular Montreal residents.

The original client was the City of Montreal, which did not have the expertise and experience to manage a job of that magnitude. A change in client occurred when the Province of Quebec was forced to step in and assume the role. Although the change was necessary, additional difficulties, such as communication problems, typically occur when the major constituents change during a project. In addition, the relationship of the design professionals hindered prompt communication. The client, architect, design engineers, and project management did not function as a team.

The weather contributed to the problems, particularly because weather protection and heating were needed, especially for the concrete work and installation of the posttensioning tendons. The project delays pushed much of that work into the winter months.

As noted previously, this paper has been assembled from a variety of sources rather than firsthand observations. The different authors of the available published materials hold widely varying views as to the responsibility for the shortcomings. However, by and large they are in agreement on the basic facts. Care has been taken to balance the opposing viewpoints as much as possible.

\section{Acknowledgments}

This material is based on work supported by the National Science Foundation under Grant No. 0919487. The conclusions and content are gleaned from available published materials and are not the opinions of ASCE. This case study was originally drafted by the first author as an honors thesis as part of the requirements of Cleveland State University's undergraduate honors program. Thanks to the Olympic Park of Montréal for providing the photographs for Figs. 1, 6, and 7. Any opinions, findings, and conclusions or recommendations expressed in this material are those of the author(s) and do not necessarily reflect the views of the National Science Foundation.

\section{References}

Auf der Maur, N. (1976). The billion-dollar game: Jean Drapeau and the 1976 Olympics, James Lorimer, Toronto.

Billington, D. P., and Billington, D. P., Jr. (2006). Power, speed, and form: Engineers and the making of the twentieth century, Princeton University Press, Princeton, NJ.

"Court hears arena suit." (1983). ENR, Oct. 20.

D’Appolonia, E. (1990). "Monitored decisions.” J. Geotech. Eng., 116(1), 4-34.

"Experts slam the Olympic structures of Montreal." (1976). Civil Engineering, Dec., 46(12), 50-54.

"Experts studying rips in roof of Montreal stadium." (1989). ENR, Dec. 13.

"55-ton concrete beam falls from Montreal stadium." (1991). ENR, Sep. 23, 9.

"Fire damages stadium mast." (1986). ENR, Sep. 11.

"Fixing the roof with a fixed roof." (1983). ENR, Jan. 15.

Fotheringham, A. (1999). "The woes of the Olympics began in Montreal." Macleans, 112(6), 76.

Howell, P. C. (2009). The Montreal Olympics: An insider's view of organizing a self-financing games, McGill-Queen's University Press, Montreal.

Kidd, B. (1992). "The culture wars of the Montreal Olympics." Int. Rev. Sociol. Sport, 27(2), 151-162.

Neil, J. (1979). Construction cost estimating concepts and their applications, Prentice-Hall, Englewood Cliffs, NJ, 1-8.

Parc Olympique Quebec. (2011). 〈http://www.rio.gouv.qc.ca/〉(Jun. 17, 2011).

Province of Quebec. (1980). Report of the Commission of Inquiry on the Cost of the Twenty-First Olympiad: 1980, Vols. I and II, Les Presses du Service des Impressions en regie du Bureau de l'Editeur official du Quebec, Quebec.

"Quebec's big owe stadium debt is over." (2006). CBC News, Dec. 19, 〈http://www.cbc.ca/canada/montreal/story/2006/12/19/qc-olympicstadium .html $\rangle$ (Jun. 10, 2011).

"Stadium fabric roof tears again." (1999). ENR, Feb. 9.

Strenk, A. (1978). "Back to the very first day: Eighty years of politics in the Olympic Games." J. Sport Social Issues, 2(24), 1-6.

"Suspect steel will keep stadium close." (1991). ENR, Sep. 5. 